\title{
The green certification adapted to Brazil: in search of efficiency and sustainability in buildings
}

\begin{abstract}
Background: With growing environmental concern, green building certification is gaining ground in Brazilian cities. Concepts such as water and energy efficiency are competitive instruments in the real estate market of the Country. Thus, the objective of this work is to present three certifications adapted to the case of Brazil, based on European stamps known worldwide. The first, AQUA is based on the French label Haute Qualité Environnementale, the other two, the Blue (Selo Azul) and Procel stamps, all nationally, have as aim, the environmental certification in particular, of social housing and energy efficiency issues. Three case studies are presented as examples. As a conclusion, the search for the green stamp has a initial investment, however, this becomes a gain in the corporate image of the company and on its profits.
\end{abstract}

Keywords: Brazilian green stamps, energy efficiency, procel stamp, high environmental quality (AQUA stamp), blue stamp (Selo Azul)
Volume 5 Issue 2 - 2019

\author{
Vanessa Meloni Masara \\ Adjunct Researcher, University of São Paulo, Brazil
}

Correspondence: Vanessa Meloni Massara,Adjunct Researcher, Polytechnic School, University of São Paulo, Brazil, Tel+55 I 97567 9973, Email vmmassara@usp.br

Received: May 17, 2019 | Published: May 23, 2019

\section{Introduction}

The concept of sustainability that is much debated today has had its first studies in the 1950s. In the 1970s, Ignacy Sachs suggested the word "eco-development" as a compromise term that sought to reconcile increased production with the ecosystems preservation. With the Brundtland Report (Stockholm Conference, 1972) the definition officially enters the world pattern. ${ }^{1}$

In Brazil, attention to the subject grew in the 1st. ONU Conference on Development and Environment - ECO92 - through Agenda 21 and its multi-sectoral approach to the Brazilian reality, considering the environment, society, economy and the city as a whole. The main issues raised were water consumption, solid waste generation and air pollution.

The next Brazilian instrument that considered the issue of urban sustainability, was the Statute of the City (Law 10257 of July 10, 2001, Brazil, 2001), which organized urban, tax and legal instruments, aiming that the Director Plan of all Cities, could establish the development of social functions of the city and urban property, including the concept of sustainable cities for the current and future generation.

To this end, the Brazilian Council for Sustainable Construction (CBCS) was created in 2007 with the objective of disseminating the use of sustainable practices in the civil construction sector, and began to spread the concept that is now known in Brazil as: "Sustainable construction means reducing environmental impact, reducing rework and waste, ensuring product quality with end user comfort, reducing energy and water consumption, hiring labor and using materials produced in accordance with the principles of legislation, reduce, recycle and reuse materials". ${ }^{2}$

\section{Methods}

The main foundation of sustainability and environmental certification of Brazilian buildings is supported by three areas of concentration:

1. Characteristics of the environment.

\section{Energy efficiency.}

3. Water efficiency. ${ }^{2}$

Regarding the project environment, the green stamp analyzes the quality of life of the region where the project is located: infrastructure, services and quality of life in general.

Regarding energy efficiency, studies on various aspects of rational energy use are associated with environmental certification:

1. Solar energy for water heating.

2. Thermal performance of the building material functioning as a thermal insulation.

3. Use of colors and cool roof aiding in the capture of heat and natural light.

4. Light bulbs with lower consumption and longer service life, eg LED.

5. Green roofs and vertical gardens that behave like thermal insulation.

Regarding water efficiency, the concession of green stamps analyzes the use of resources that optimize consumption, such as:

\section{Use of rainwater.}

2. Water-saving components (toilets with coupled flushing boxes, taps with sensors).

\section{Reuse of water.}

Much of this scope is associated with climatic characteristics of the northern hemisphere that are very different from Brazilian conditions. In this way, the adaptation of the certification criteria is of paramount importance for its perfect implementation.

${ }^{1}$ The definition of energy efficiency can be summarized as: obtaining the best performance in the production of a service with the lowest energy expenditure. ${ }^{2}$ The definition of water efficiency is related to the reduction of water waste, not the restriction of its use; ie, the optimization of consumption. 


\section{Aqua stamp}

AQUA stamp is derived from the French Haute Qualite Environnementale certification. In Brazil, this certification has been represented since 2007 by the Vanzolini Foundation of the University of São Paulo. In 2008 the Foundation participated in the Sustainable Building Alliance, with representatives from France, England, Germany, Italy and Finland to define the standardization of crosscountry evaluation. "High Environmental Quality" (AQUA) is defined as: a project management process aimed to obtain the environmental quality of a new undertaking or involving a rehabilitation".

It uses the same 14 French process criteria grouped into 4 research groups: ${ }^{4}$

a. Construction: integration, materials and bedding.

b. Management: energy, water, waste, maintenance.

c. Comfort: thermal, acoustic, visual and olfactory.

d. Health: quality of air, water and space.

These four groups are disaggregated into several items. ${ }^{5}$ In each item there are still other sub-divisions during the inspection of the construction. ${ }^{3}$ Taking the case of 'Energy Management' are verified the factors:

1. Hot water production system and its consumption.

2. Hot water production system using renewable energies.

3. Individual production of hot water by solar panels.

4. Collective production of solar hot water.

5. Production of electric energy using photovoltaic panels.

6. Hot water system by heat pump.

After the inspection, a score range is assigned per criterion that is associated with a level of environmental excellence that will represent the type of certification that the project/construction is capable of receiving, from the minimum level of performance to excellence, as shown on Table 1.

Table I AQUA score assignment

\begin{tabular}{ll}
\hline Score Rabge (Criteria) & $\begin{array}{l}\text { Level of energy } \\
\text { excellence }\end{array}$ \\
\hline Maximum performance & Great \\
Good practice performance & Higher \\
Minimum performance required & Good \\
\hline
\end{tabular}

Source: FCAV. ${ }^{3}$

\section{Selo azul (blue stamp)}

Blue Stamp (Selo Azul, in Portuguese) was created in 2010 by Caixa Econômica Federal, ${ }^{6}$ it was developed in partnership with the University of Campinas, the University of São Paulo and the Federal University of Santa Catarina. It is classified as a voluntary socioenvironmental classification of housing development projects, being applicable to financing projects. ${ }^{6}$

According to John and Prado, ${ }^{7}$ the Selo Azul (Blue stamp) aims to reduce consumption of natural resources and prolonging the useful life of buildings. The analysis is indebted in 6 groups totaling 53 factors: i. Urban Quality: 5 criteria (2 mandatory: Infrastructure and Impacts and 3 facultative).

ii. Design and Comfort: 11 criteria (5 compulsory: Landscaping; Selective site; Leisure, social and sports equipment; Thermal performance; Thermal Performance - Orientation to Sun and Winds and 6 facultative).

iii. Energy Efficiency: 8criteria (3 compulsory: Low Consumption Lamps - Privative Areas; Saving Devices - common areas; Individualized Measurement - Gas and 5 optional).

iv. Conservation of Materials Resources: 10 criteria (3 mandatory: Quality of Materials and Components; Reusable Forms and Anchors.

v. Water Management: 8 criteria (2 mandatory: Individualized Measurement - Water; Permable Areas and 6 facultative).

vi. Social practices: 11 criteria (3 compulsory: Education for Waste Management; Environmental Education; Guidance for Residents and 8 facultative).

The certificate is granted to the project / construction that obeys to 19 criteria (bronze stamp); 25 criteria (silver stamp) and 31 criteria (gold stamp), as shown on Table 2.

Table 2 Blue Seal (Selo Azul) score assignment

\begin{tabular}{ll}
\hline Score Rabge (Criteria) & $\begin{array}{l}\text { Level of energy } \\
\text { excellence }\end{array}$ \\
\hline $\begin{array}{l}\text { Obey the } 19 \text { criteria }+12 \text { free } \\
\text { choice }\end{array}$ & Gold \\
Good practice performance & Silver \\
Obey the 19 criteria & Bronze
\end{tabular}

Source: Motta. ${ }^{6}$

\section{Procel stamp}

The National Program for Energy Efficiency in Buildings (in Portuguese: PROCEL EDIFICA) began in 2003, with cooperation of the Ministry of Mines and Energy, of the Ministry of Cities, of Eletrobrás and some Universities. The stamp created in 2014, is voluntary and specifically addresses energy efficiency issues. Procel says that its use can save $50 \%$ of energy.

The criteria for analysis are based on the 'Technical Quality Regulation for the Energy Efficiency - Level: Commercial, Services and Public Buildings' (RTQ-C) and' Quality Technical Regulation for the Energy Efficiency - Level: Residential Buildings' (RTQ-R). ${ }^{8}$

Depending on the use type of the building, there is a process for its 'labeling'. In residential and service buildings, evaluation occurs in two phases: in design and in post-construction. For this, there are four types of stamps: ${ }^{8}$

i. National Energy Conservation Label of Autonomous Housing Unit.

ii. National Tag of Energy Conservation of Autonomous Housing Unit.

iii. National Energy Conservation Label Multi-family building.

iv. National Energy Conservation Label of Common Use Area. 
For certification ${ }^{8}$ the verification and analysis of the building areas adequacy consider:

1. Lighting: Glass windows; Glazed walls; Glass brick walls; closed gaps with polycarbonate or acrylic plates; zenith opening; natural lighting.

2. Ventilation: environment artificially conditioned; ventilation potential; cross and natural ventilation.

3. Lighting and solar ventilation for months of the year depending on the State inside the Country.

4. Type of use (number of hours / day, times); areas of common use; lifts in standby or in use.

5. Types of frames; coefficient of airflow through cracks; roughness of the environment around the building.

6. Coefficient of performance; type of envelope (facades, coverings and their materials); room dimensions; cross and natural ventilation.

7. Brazilian bioclimatic zoning (map).

Procel ${ }^{8}$ certification is awarded for buildings with a score greater than 1.5 (range E) up to 4.5 points (range A, higher efficiency) as shown on Table 3 .

Table 3 Assignment of Procel score

\begin{tabular}{|c|c|c|c|}
\hline \multicolumn{2}{|c|}{ Score range (SR) } & & \multirow[t]{2}{*}{$\begin{array}{l}\text { Level of energy } \\
\text { excdellence }\end{array}$} \\
\hline E & D & B & \\
\hline \multicolumn{3}{|c|}{$S R \geq 4,5$} & $A$ \\
\hline \multicolumn{3}{|c|}{$3,5 \leq \mathrm{SR}<4,5$} & B \\
\hline \multicolumn{3}{|c|}{$2,5 \leq \mathrm{SR}<3,5$} & C \\
\hline \multicolumn{3}{|c|}{$\mathrm{I}, 5 \leq \mathrm{SR}<2,5$} & D \\
\hline \multicolumn{3}{|c|}{$S R<1,5$} & $\mathrm{E}$ \\
\hline
\end{tabular}

Source: Procel.$^{8}$

\section{Results}

The project known as Alliance Verte (Green Alliance) is a milestone in AQUA certification in Brazil. It was designed through the reuse of materials from demolition. Thus, concrete, steel, wood and plastic were recycled and the construction system was based on lightweight metallic structures.

The walls were raised in concrete blocks. In the façade, the blocks are covered by OSB (Oriented Strand Board), wood boards from reforestation wood. Thermal insulation was obtained by pet bottle wool.

The floor was made of rubber with used tires; all the paint, used water-based paint; drywall boards were used in the partitions. ${ }^{9}$

In the area of energy efficiency, the building has ecological roof, terraces with landscape design that reduce thermal shock and a vertical garden. In the roof were inserted plates of solar energy. The project studied the use of light and natural ventilation $(95 \%$ of the internal spaces have natural light entrance); the frames have double glazing with shutters or thermal films. The system of lighting used lamps of 500lux (low consumption). The apparatuses for the conditioned air were equipped with filters and have stamps of energy efficiency.

For the water efficiency was executed a project of reuse of rain water for use in sanitary basins, faucets with flow control and 100\% draining external floor, with $98 \%$ rainwater absorption.

The investment resulted in savings of $30 \%$ to $50 \%$ of water consumption (depending on rainfall volume) and energy savings of $36 \%$, with $13 \%$ of energy production by the solar matrix. ${ }^{10}$

In 2010, a competition was proposed by the Rio de Janeiro City Hall, for the environmental qualification of a project in low-income communities, through a partnership with the Brazilian Business Council for Sustainable Development (CEBDS) and UN-Habitat.

The winning project entitled Morar Verde Carioca (favela of Babilônia and Chapeú, Rio de Janeiro, capital) was completed in 2012 is a part of the Municipal Plan for Integration of Informal Slums.

This project received the Blue seal (Selo Azul) with gold certification meeting the maximum requests for environmental excellence stipulated by the Federal Savings Bank (in portuguese, Caixa Econômica Federal). ${ }^{11}$

Noteworthy are the squares built with recyclable material; the use of solar heating for showers; the use of alternative materials that don't waterproof the soil, such as drainage and micro-gardening; LED street lighting and selective recyclable waste.

With reference to the building material, the metal structure used, was reused from another building and the walls raised with ecological brick; either, a rainwater reuse project was carried out. ${ }^{11}$

As an example of PROCEL stamp, Hangar Business Park (Salvador, Bahia) was a project developed in 2014 that was made up of seven commercial towers and has received classification level A, for having obtained the maximum score with reference to energy efficiency. To achieve this goal, the buildings adapted their envelope to use natural light as much as possible (through the use of brises) and natural ventilation. Air conditioners with high performance were used saving $32 \%$ of electricity.

The lobbies, in addition to use natural lighting, were designed for ceiling and dichroic LED and magnetic induction lamps, providing savings in the range of $56-88 \% .12,13$

Intelligent traffic control in elevators and solar panels for water heating were also used. This project highlights the energy efficiency associated with landscaping and was a landmark in environmental certification, located in the northeast region of Brazil.

\section{Discussion}

As discussed in this paper, sustainability in civil construction presents several approaches that start from a well structured building project considering correct materials and when possible, reused, studies of the envelopment, thermal insulation, lighting and ventilation that take advantage of solar radiation and winds, landscaping through green roofs and vertical gardens, rainwater harvesting and reuse, water saving equipment, solar panels, low consumption lamps and even the choice of color and external and internal walls.

The project environment must also present services, infrastructure and accessibility. Although the investment results in an increase of approximately $5 \%$ in the total cost of the work, the return of this value 
occurs in the medium term (estimated between 2 to 5 years), due to the saving of water, energy, maintenance and waste management. The corporate image of the company also wins by raising awareness and obtaining a certificate valued at international levels.

\section{Conclusion}

With growing environmental concern, green building certification is gaining ground in Brazilian cities. The introduction in Brazil of green certification should gradually become an important mechanism for building awareness, not only for the socio-environmental issue, but also, as a factor of valorization of the enterprise and a key instrument for obtaining financing and participation in public bids.

\section{Acknowledgments}

None.

\section{Conflicts of interest}

The author declares that there is no conflict of interest.

\section{References}

1. Veiga JE. Sustainable development: the challenge of the $21^{\text {st }}$ century. Rio de Janeiro, Brasil: Editora Garamond; 2005.

2. Leite VF. Environmental certification in construction - LEED and AQUA systems. Escola de Engenharia da Universidade Federal de Minas Gerais. Belo Horizonte: UFMG; 2011.
3. Fundação Vanzolini - FCAV. Technical reference for certification "Residential buildings - Process AQUA". Brasil: FCAV; 2013.

4. GBC Brasil Casa ${ }^{\circledR}$. Practical guide: why and how to certify your project. São Paulo, Brasil: GBC Brasil; 2012.

5. France GBC. International environmental certifications for the design and construction of non-residential buildings. France GBC: France; 2016.

6. Motta MLA. Blue House stamp by Caixa (Selo Casa Azul Caixa). São Paulo, Brasil: Caixa Econômica Federal; 2010.

7. John VE, Prado TA. Good practices for more sustainable housing. São Paulo: Páginas \& Letras; 2010.

8. Centro Brasileiro De Informação De Eficiência Energética - Procel. 2017.

9. Arcoweb. Aliança Francesa building in Rio de Janeiro receives AQUA certification. 2017.

10. Brasil Engenharia. Aliança Francesa headquarters in Rio receives AQUA certification. 2017.

11. Rangel J. Sustainable communities - the example of "Morar Carioca". 2019.

12. Odebrecht Realizações Imobiliárias. Hangar Business Park - the project. Salvador: Odebrecht, 2014.

13. Estatuto da cidade. 2001. 